Article

\title{
Integrating Big Data into a Sustainable Mobility Policy 2.0 Planning Support System
}

\author{
Ivana Semanjski ${ }^{1, *}$, Rik Bellens ${ }^{1}$, Sidharta Gautama ${ }^{1}$ and Frank Witlox ${ }^{2,3}$ \\ 1 Department of Telecommunications and Information Processing, Ghent University, 9000 Ghent, Belgium; \\ rik.bellens@ugent.be (R.B.); sidharta.gautama@ugent.be (S.G.) \\ 2 Department of Geography, Ghent University, 9000 Gent, Belgium; frank.witlox@ugent.be \\ 3 Department of Geography, University of Tartu, 51014 Tartu, Estonia \\ * Correspondence: ivana.semanjski@ugent.be; Tel.: +32-9-264-3410
}

Academic Editor: Brian Deal

Received: 9 September 2016; Accepted: 1 November 2016; Published: 7 November 2016

\begin{abstract}
It is estimated that each of us, on a daily basis, produces a bit more than 1 GB of digital content through our mobile phone and social networks activities, bank card payments, location-based positioning information, online activities, etc. However, the implementation of these large data amounts in city assets planning systems still remains a rather abstract idea for several reasons, including the fact that practical examples are still very strongly services-oriented, and are a largely unexplored and interdisciplinary field; hence, missing the cross-cutting dimension. In this paper, we describe the Policy 2.0 concept and integrate user generated content into Policy 2.0 platform for sustainable mobility planning. By means of a real-life example, we demonstrate the applicability of such a big data integration approach to smart cities planning process. Observed benefits range from improved timeliness of the data and reduced duration of the planning cycle to more informed and agile decision making, on both the citizens and the city planners end. The integration of big data into the planning process, at this stage, does not have uniform impact across all levels of decision making and planning process, therefore it should be performed gradually and with full awareness of existing limitations.
\end{abstract}

Keywords: big data; smart city; decision making; sustainable mobility; transport planning; Policy 2.0; smartphones; urban data analytics

\section{Introduction}

It is a fact that at the beginning of this century the amount of data then available in the entire Internet equals to what is now created in a single second. Mobile phones, social networks, surveys, bank card payments, Global Navigation Satellite Systems (GNSS), online activities, public transport ticketing, location-based services, etc. all produce torrents of data as a by-product of their operations. Comparing the amount of data generated in 2011 with its growth and global population size [1], it is estimated that on average each person produces $1 \mathrm{~GB}$ of content daily. This huge data stream initiated revolution is being referred to as big data. The term big data is used as a general term for referring to data sets so large and complex that traditional data processing applications are no longer adequate. This fundamental change of going from a data-scarce to a data-rich environment seems to infer a shift from relatively "small data" studies aimed to answer specific questions based on sampled data to "big data" studies that aim at probing for relationships and correlations between a wide series of variables and contexts [2]. Big data is often typified by the so-called 3Vs definition [3]. The three Vs define big data as the increase of volume (data scale becomes increasingly big), variety (data come as structured, semi-structured and unstructured data) and velocity (data collection-processing chain needs to be promptly and timely conducted to maximally utilize the potential value of big data). 
Over time, gleaning intelligence from data proved itself to be a key element that differentiates between, simply, large data amounts and big data itself. In evidence of this is the growing body of scientific literature on this topic that is exhibiting exponential growth over the last five years (Figure 1). Thus, the original definition evolved towards $4 \mathrm{Vs}$ [2-5], which is the most used today. In the 4Vs definition, original velocity was divided into velocity and value, highlighting the extraction of value from data as one of the main big data characteristics. Hence, the $4 \mathrm{Vs}$ stand for volume (great volume), variety (various types of data), velocity (swift generation), and value (huge information value with very low density concealed among data). Companies that have, at early stage, recognized this potential demonstrate a strong role that data driven insights have in gaining business advantage. Many examples of this, such as Amazon [6] or Google [7], are well known today [8,9]. As the availability of data to measure the system performance and consumer behaviour is strongly influencing the level of knowledge about their businesses and consumers, managers are able to directly translate that knowledge leads to improved decision making and performance. This makes their business more agile and resilient, while facing upcoming challenges.

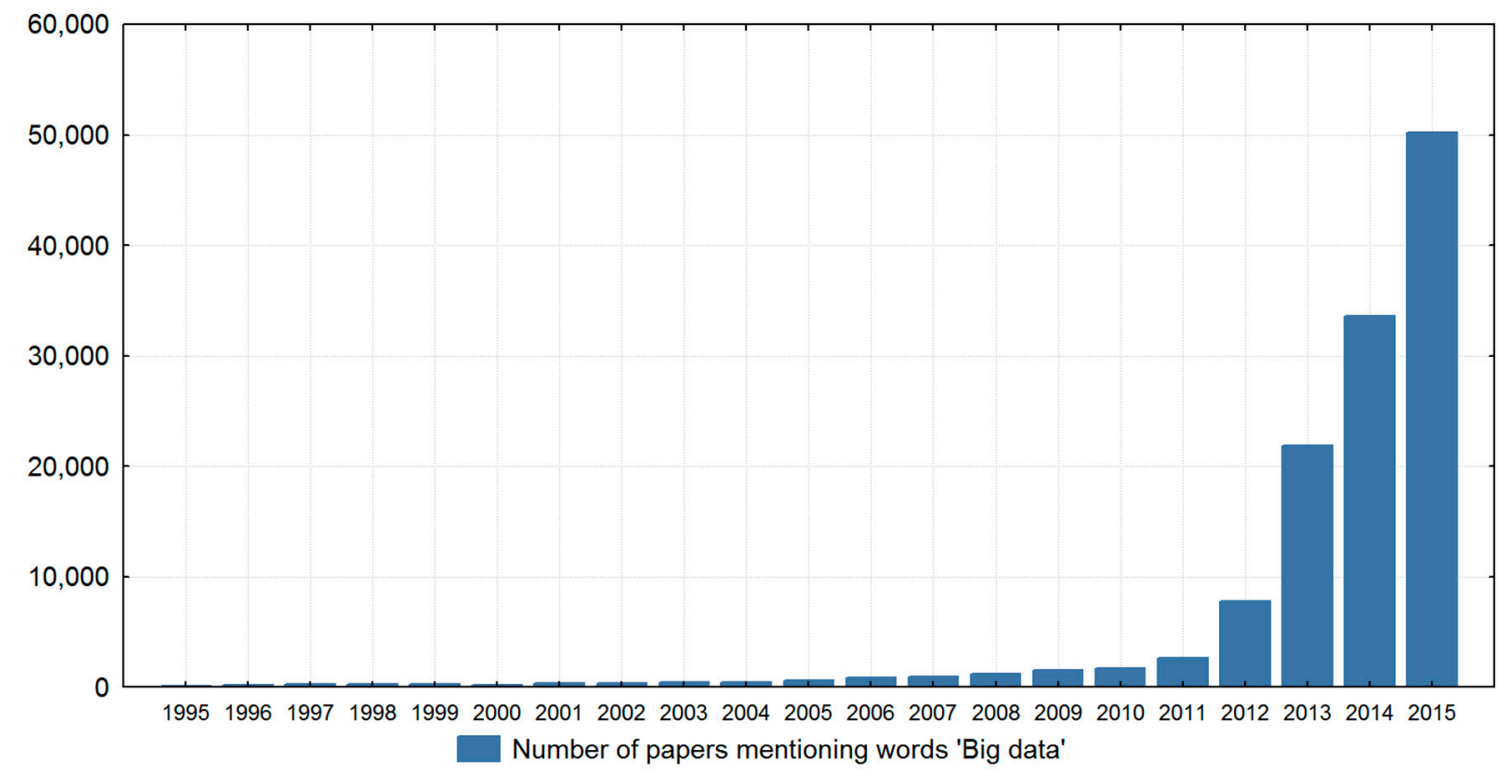

Figure 1. Number of scientific papers that mention words "big data" (based on [10]).

The first wave of business-oriented big data applications is slowly flowing into other spheres like city assets and systems management. This is mainly captured by a concept of smart cities which has been the subject of increasing attention over the past years [11-23]. Smart cities refer to urban settlements that consciously aim at increasing citizens' quality of life by capitalizing on existing data generation. In more detail, they integrate physical, information and communication, social and business infrastructure to leverage the collective intelligence of the city by ensuring better management of city's assets. In this sense, Piro et al. [24] explore how the collection of measurements and status information from household elements can be implemented in more intelligent home management system. For this purpose, they adopt a so-called data networking architecture as a connection point between communication network's service and technological layer. Filipponi et al. [25] suggest event driven architecture that allows the management and cooperation of heterogeneous sensors for monitoring public spaces, whereas Wan et al. [26] explore tendencies in machine to machine communications development that could support the construction frame of such architecture. Next to the focus on system architecture, Versichele et al. [27] demonstrate the implementation of Bluetooth-based crowdsourced data for monitoring crowd behaviour during festivities organised in a city. They use crowdsourced data for supporting city event management for 
the organization, security, transport and emergency service providers. Furthermore, Balakrishna [28] examined in more detail enabling technologies for city services and applications. These, and many other, promising initiatives have emerged over the years capitalizing on ubiquitous data presence and impacting different aspects of urban living. However, contrary to research in the artificial intelligence field, where data and intelligence are joined to enable machines (computer programs) to mimic human cognitive functions, such as learning and problem solving, smart cities are dominantly people centric. Thus, although the smart city concept strongly relies on machine learning algorithms (which originally evolved within artificial intelligence field) to extract knowledge from data, they are harvesting on data to empower citizens and authorities in making more informed decisions [29]. Therefore, we see the strongest role for big data within the smart city concept in its ability to support decision making and planning processes. However, implementation of big data in these processes remains a rather abstract idea for several reasons, including the facts that practical examples are still strongly services oriented, and that it refers to still largely unexplored and interdisciplinary field hence missing the cross-cutting dimension [12,13,17,30-32]. In this context, the present contribution formulates a pioneering proposal, by drawing a Policy 2.0 concept and exploring the real-life use case where Policy 2.0 platform is used in supporting sustainable mobility related planning. The idea of Policy 2.0 platform for smart cities has been already discussed (but only in a preliminary formation) in Semanjski et al. [33]. In this paper, the authors significantly extend their previous contribution by detailing how data driven insights can contribute to decision making and smart city's planning processes based on a Policy 2.0 platform. In particular, the main goals of this contribution can be summarized as follows: (i) we define the Policy 2.0 concept; (ii) we demonstrate, in a real-life example, the impact of big data availability on decision making and planning process; and (iii) we systemize potential implications that the integration of big data into planning process can have in favour of improved quality of life and smart and sustainable growth of future urban agglomerations. The rest of the paper is organized as follows. In Section 2, the Policy 2.0 concept is defined. Section 3 provides a description of Policy 2.0 real-life example. Section 4 describes in more detail data driven insights and impact on planning and decision making process. Finally, Section 5 provides discussion on the topic and is followed by conclusions and forecasts future research.

\section{Policy 2.0}

The 2.0 concept originates from web domain where it was used to differentiate between Web 1.0 and Web 2.0 [34]. Web 1.0 sites are considered to be content driven and Web 2.0 concept moved beyond this point as Web 2.0 site allows users to interact and collaborate with each other in a social media dialogue. This way users' role evolved towards creators of user generated content. Examples of Web 2.0 include social networking sites, blogs, wikis, video and image sharing sites, web applications, etc. Even though the term may suggest that Web 2.0 is a newer version of the web, there was no actual new technical modification but the difference lies in the way users experience and participate in content (data) generation. These significant societal changes driven by Web 1.0 and 2.0 were later linked to Sustainability 1.0 and 2.0 concepts $[35,36]$ as the role of sustainability changed in relation towards companies' business objectives. Sustainability 2.0 represented concept of perceiving sustainability as a catalyst for rethinking business models, products, technologies and processes rather than initially grasped as simple corporate social responsibility. A similar evolution is currently happening within the smart cities concept as data-driven changes influence the way decision making and planning is carried out. In this process probably the most profound transformation is linked with the citizens' role in the process, enabled two way timely communication and relevant content provision. This is evident from the generation of crowdsourced voluntary provided information like the OpenStreetMap (OSM) project [37] that can, and is, effectively used in many planning and decision making related activities. Some examples of this include mapping of the current status of roads, towns, and villages, supporting the coordination of help efforts from government institutions and civil society rescue initiatives after the earthquake in Ecuador (16 April 2016) [38] and Nepal (25 April 2015) [39] 
or providing geo-located information on Polio outbreak in rural Cameroon to support World Health Organization (WHO) and the Centre for Disease Control and Prevention (CDC) planning and decision making activities (October 2013) [40]. The prevailing role of citizens' generated content in urban area was also demonstrated after the security lockdown on Brussels (November 2015), including the closure of shops, schools and public transport, due to information about potential terrorist attacks [41]. During this period the authorities explicitly asked users of social media networks to desist from disclosing details of police operations in their area. Unable to share content about the events that were unfolding, the social networks-users decided to while away the time by sharing images of their cats (a reference to security level Four, or in French, "quatre" pronounced similar to English word "cat" [42]). The authorities later thanked for this effort by posting the image of cat's treats on their social media profile [43]. These types of interactions were almost unimaginable a decade ago, and have greatly affected the way citizen-authority communication is realised. The idea that something that happened yesterday is still new and has information value assigned to it (as perceived by traditional media) is strongly changed by this participative content generation. However, user generated content is not only relevant in situations initiated by an extreme event, although today it has strong and sometimes prevailing role, but also in our everyday lives. In an attempt to generalize this effect, we distinguish between Policy 1.0 and 2.0 in regard to eight axes as defined in Table 1.

Table 1. Policy 1.0 and Policy 2.0 axes.

\begin{tabular}{ccc}
\hline & Policy 1.0 & Policy 2.0 \\
\hline Interaction & Closed & Collaborative \\
\hline Participation & Individual participation & Group (citizens) Participation \\
\hline Communication & One-Way Communication & Two-Way Communication \\
\hline Involvement & Passive Involvement & Active Involvement \\
\hline Content & "Read-Only" Content & “User (citizens)-Generated" Content \\
\hline Motives for change & $\begin{array}{c}\text { Often include risk aversion and } \\
\text { reputation management }\end{array}$ & $\begin{array}{c}\text { Are more likely to include innovation, } \\
\text { focus on creating shared value }\end{array}$ \\
\hline External communication & $\begin{array}{c}\text { External communication is } \\
\text { dominated by public relations } \\
\text { Sustainability }\end{array}$ & $\begin{array}{c}\text { External communication is driven } \\
\text { by engagement }\end{array}$ \\
\hline & a responsibility & $\begin{array}{c}\text { Sustainability is positioned central } \\
\text { to strategy }\end{array}$ \\
\hline
\end{tabular}

Thus, we see Policy 2.0 as innovation and data generation driven decision making and planning concept that actively involves citizens in collaborative content generation with aim to ensure increased quality of life and co-creation of more sustainable communities. The concept is applicable across all decision making and planning levels as big data driven insight can support:

- Strategic activities by providing high level aggregated information that is extracted from user generated big data. Hence, such data are able to give insight into long term time series (e.g., spatial movements of population or environmental conditions) and ensure effective use of prediction models to support long-term planning.

- Tactical decision making by ensuring coverage of diverse aspects of user related activities. Thus big data are being able to support different administrative departments with relevant information needed to implement strategic decisions (e.g., evaluating infrastructure and how it operates, establishing communication channels, structuring workflows, acquisition of resources, etc.).

- Operational decisions by supporting day-to-day operations with short-term horizon insights (e.g., real time information on the status of public transport service). 


\section{Policy 2.0 Platform}

\subsection{Sustainable Mobility Campaign}

To illustrate the applicability of Policy 2.0 concept on urban decision making and planning process we report on collaborative content generation that was generated in Leuven, capital of the province of Flemish Brabant (Belgium), as a part of sustainable mobility campaign. The campaign was conducted under the New Integrated Smart Transport Options (NISTO) project that aimed to develop an evaluation and planning toolkit for mobility projects [44]. The campaign itself lasted from January to June 2015 and was motivated by integration and active involvement of all stakeholders into mobility planning process. For this purpose, a smartphone application for Android platform, called Routecoach [45], was developed at Ghent University. The application was used as "routing coach" enabling citizens to voluntary contribute their mobility data (e.g., GNSS tracks, online travel diary, answer surveys questions, etc.) and receive personalized multimodal routing information, individual and overall mobility statistics/visualizations and get involved in social network interaction (e.g., discussions, challenges and rewards in different aspects of sustainable mobility, such as the most biked kilometres per week, etc.). Overall, more than 8300 participants (approximately $8.4 \%$ of city population [46]) contributed with their data, reporting on more than 30,000 trips.

The "coaching" aspect of the campaign was to learn from user generated content and coach users towards more sustainable route choices. To do so, provided content needed to be user relevant. For example, informing somebody who is passionate car driver about alternative public transport route, with transfer, will probably fail to raise much attention. However, if car driver from the previous case is someone who finds driving stressful, and uses this option because (s)he is not aware of other possibilities, than maybe an idea to read a book while commuting will be intriguing one. Having this in mind, feedback given to the user needs to be in line with ones attitudes towards different mobility options and motivation to change habitual mobility behaviour. For this reason, we adopted the results of the European project Segment [47] that applied the theory of planned behaviour [48] to sustainable mobility field. The theory of planned behaviour proposes that behaviour is proximally caused by intention to perform that behaviour or, in more detail, by three conceptually independent determinants:

- Extent to which a person believes that the behaviour in question is under his or her control;

- Person's attitude toward the behaviour; and

- Perceived social pressure to perform or not to perform the behaviour in question.

In line with this, the Segment project defined a short survey (eighteen questions) that differentiates the most between eight different user profiles [47]. Thus, the survey explores to which extent a person believes that sustainable mobility related choices are under his or her control (e.g., does person believes that change in his/her behaviour will have any impact on $\mathrm{CO}_{2}$ emissions reduction), what are person's attitudes toward differed sustainable mobility options (e.g., does person finds cycling stressful or enjoyable) and what is person's perceived social pressure related to the mobility options (e.g., does person see use of private vehicle as a way of self-expression). The complete description of survey creation, full list of questions and user profiles are described in detail in Anable and Wright [49] and Ladbury [50]. For clarity of our study, Table 2 summarises the characteristics of each of these profiles. 
Table 2. Sustainable mobility profiles.

\begin{tabular}{cl}
\hline Profile & \multicolumn{1}{c}{ Description } \\
\hline & $\begin{array}{l}\text { They prefer to use a car and are not convinced that there are realistic alternatives } \\
\text { to private car to most of the journeys they make. They tend to think successful } \\
\text { people use cars and that it is a way of self-expression. They do not see themselves } \\
\text { as a public transport (PT) user or a cyclist and consider modes, other than car, } \\
\text { to be too slow and often stressful with few, if any, advantages over the car. } \\
\text { They are not particularly motivated to use their travel time to get fit by using the } \\
\text { bike or walking, and are also not particularly motivated by reducing their } \\
\text { emissions of greenhouse gases. They believe that car use should not be restricted } \\
\text { and would like to see more roads built to reduce congestion. }\end{array}$ \\
\hline
\end{tabular}

They like to drive and do not want their ability to drive to be restricted. The main reason for this is largely practical but they also feel that car driving is part of who they are and their identity. They recognize that it would be good for the planet if Image Improvers $\quad$ we all would reduce our car use a little but are not entirely convinced about the but at the same time they want to do the right thing. They do not relate to PT users but are likely to see cycling as a form of self-expression and are interested to keep fit. They are also likely to think they should walk more but consider walking to be too slow.

They drive a lot but find it increasingly stressful. They want to cut down their car use but find that there are a lot of practical problems with using alternative modes (e.g., they are likely to feel that PT provision in their area is inadequate). Although they consider that cycling might be beneficial to their health, it is not

Malcontent Motorists something they feel comfortable doing. They walk sometimes (rather for practical reasons than fitness), although they would like to walk more in the future. Environmental issues are something they are aware of and know a little bit about, but they do not feel it is practical to make decisions about their daily travel based on these issues.

They would like to decrease their car use, especially on short journeys, but they do not see the PT as a solution (even though they consider it can sometimes be quicker). The main reason for this is largely practical e.g., for carrying things or travelling with children. Their most preferred alternatives are walking and

Active Aspirers cycling. They walk a lot already because they see it as healthy and enjoyable and are likely to try and fit it into their daily routine as much as possible.

They consider cycling to offer freedom, speed and fitness. They are likely to be motivated by environmental issues.

They regard the car merely as a practical means for travelling and largely use it only when necessary. They walk and cycle a lot as they believe these modes can often be faster, cheaper and generally more convenient than the car. However,

Practical Travellers the PT is something they feel is often inferior because of the time it takes. They do not tend to walk or cycle for fitness, but keeping fit is important to them.

They would not change much about how they currently travel as they feel they are already making optimum choices given their commitments and what they have available to them.

They are likely to not be able to afford a car at the moment. However, they aspire to own a car in a near future as they believe it is a sign of being successful and will provide independence and freedom. Cycling is not something they want to do more of and see it as impractical and stressful mode. They see walking as practical, good for fitness and something they intend to do more of, but generally limited as a mode of transport. They see even more problems with using the PT and whilst they might use it a lot at the moment, they prefer the car for future.

Although they are not against cars and think people should be allowed to use them freely, they don't like driving very much. They consider the PT to be too slow and do not see themselves as a cyclist. They don't mind walking and would

PT Dependents like to do more of it, particularly for fitness. They have very little interest in environmental issues and do not think they concern them very much, although local pollution and congestion is a concern.

They are not keen to use the car and believe that their impacts are something that needs to be urgently addressed. They can see benefits of travelling by walking

Car-free Choosers (they see it as healthy and would like do more of it), cycling (they like the sense of freedom it gives you and feel it says something about who they are and how they feel about protecting the environment) and using the PT (they find it enjoyable and relaxing). 


\subsection{Data Collection}

Participants of the sustainable mobility campaign were able to complete the Segment project's survey as a part of registration process while activating their Routecoach application. Based on the results of this survey: (i) for users who completed the survey, one of the eight sustainable mobility profiles was assigned; and (ii) for users who did not complete the survey, the machine learning based approach with success rate of $98 \%$ (described in detail in Semanjski and Gautama [51]) was applied to map their crowdsourced behaviour to the profiles and thus to assign the profile to the user. This way, from regional context and observed behaviour, Segment profiles were mapped to wider population. For each homogeneous subgroup, personalised route coaching was designed. This meant that every time a user would reach towards routing option of the app, the app would integrate routing information from multiple sources (e.g., regional public transport company, national rail company, Google maps, etc.) to determine feasible routes by one transport mode (e.g., car, train or bike route), but also to produce feasible multimodal routes (e.g., bike-train-foot route). All feasible routing options were evaluated based on the comfort levels and preferences of each of the profiles. This resulted in displaying the five best options to the user in personalised order and with respect to the route sustainability (e.g., car route could never be the first one). Thus, every time a user would look up for the routing information, the respond (s) he would get was personalised routing incentive challenging him, or her, to consider more sustainable route option. Furthermore, the campaign participants would, by selecting the route, generate a feedback on routes they were considering and the one they would select for their journey. This feedback would also be confirmed based on the app's route tracking option (collected GNSS route points and timestamps). In addition, the campaign involved development of dedicated web portal [45]. The portal served for user registration during which the users were asked to indicate, through the geographic information system (GIS) interface, their usual routes and transport modes they utilize for these routes. Generated indications served, in future data analytics steps, as a ground truth when determining whether actual undertaken routes correspond to the participant's usual mobility behaviour or not (Figure 2).

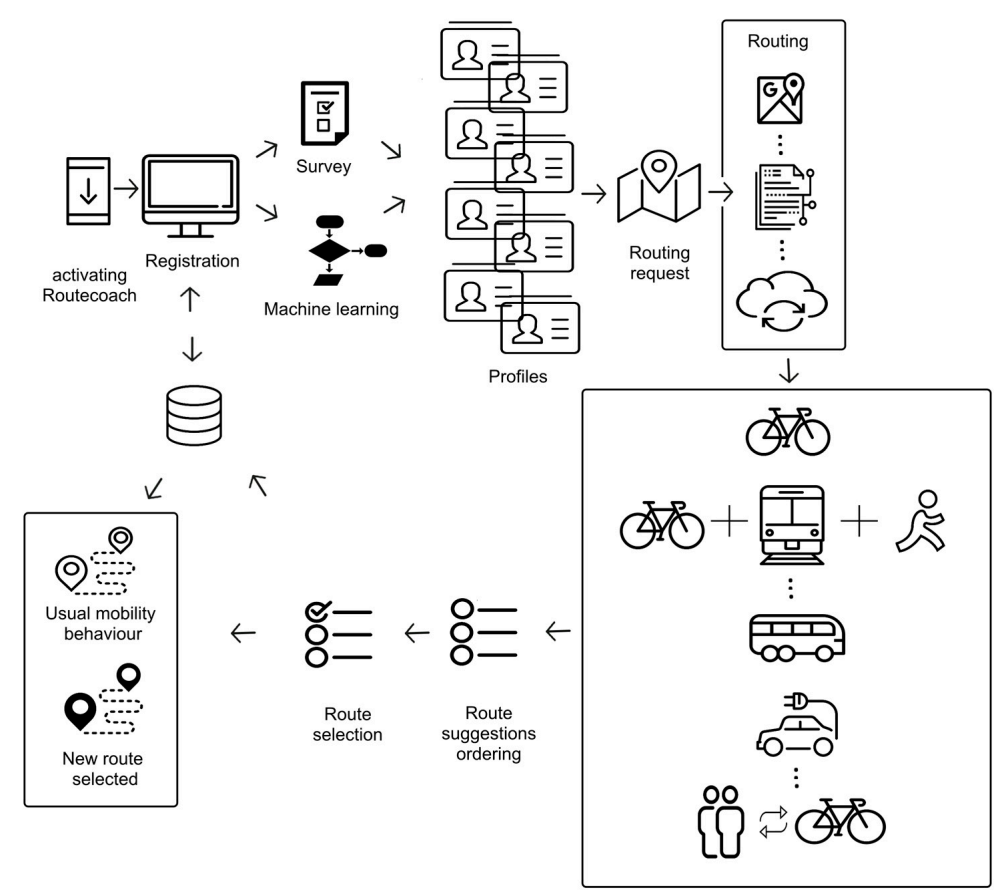

Figure 2. Data collection and processing.

Overall distribution of trips per each user profile and their acceptance of alternative route suggestions are shown on Figure 3. 


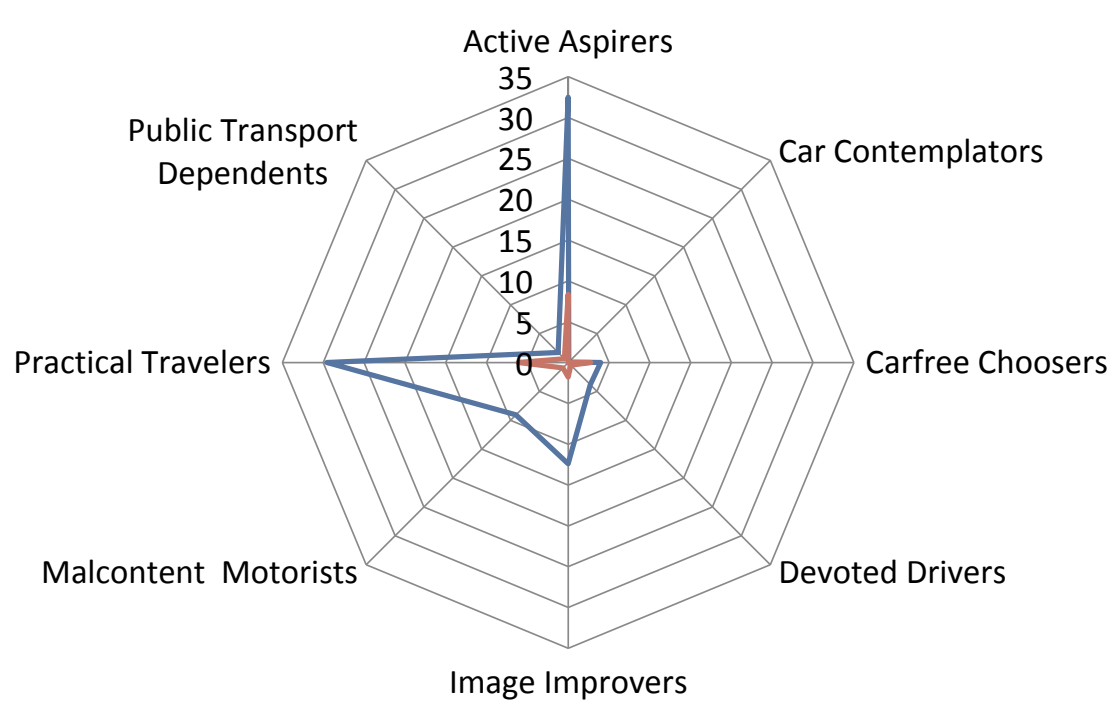

Routes - Old Behaviour — Routes - New Alternative Route

Figure 3. Distribution of trips per each user profile and their acceptance of alternative route suggestions (based on [33]).

Most of the trips, and respective users, belonged to the Active Aspirers profile. However, considering the relative share of tried alternative route options Carfree Choosers explored new routing options in highest $(18 \%)$ number of cases. Among all profiles, car oriented ones were the least sensitive towards the provided incentive as they mainly explored alternative car routes, which were shorter than the one they would usually take. More detailed description of the application, campaign, observed behavioural change and modal shifts per profiles can be found in our previous publication Semanjski et al. [33] and the campaign's/application's web sites [45,52].

\subsection{Big Data Driven Insignts}

Collected data were integrated into the Policy 2.0 platform. Insights into mobility behaviour gained from user generated content were manifold. The most direct ones were users' spatial and temporal distributions, frequency of mobility related activities and observed behavioural changes. The derived insights were result of further data processing and integration. As an example of derived insights we will report on four sustainable mobility indicators:

- Carbon dioxide $\left(\mathrm{CO}_{2}\right)$ emissions;

- Particulate matter with less than 2.5 micrometres in diameter emissions $\left(\mathrm{PM}_{2.5}\right)$;

- Calories burned by the user (kcal);

- $\quad$ Cost per trip in euros (€).

\subsubsection{Carbon Dioxide $\left(\mathrm{CO}_{2}\right)$ Emissions}

$\mathrm{CO}_{2}$ is considered to be the most significant contributor to climate change [53] among six greenhouse gas emissions stipulated by the Kyoto Protocol [54]. For this reason, it is often used as indicator for sustainable mobility [55]. Literature reports use of $\mathrm{CO}_{2}$ as equivalent of the total emission of greenhouse gases [56] or simply as direct $\mathrm{CO}_{2}$ emissions from transport [57-59]. To evaluate the sustainability of different route choice options, $\mathrm{CO}_{2}$ emissions per equal distance unit for different transport modes needed to be estimated. The National Rail Company provides detailed calculation of $\mathrm{CO}_{2}$ emission per average passenger-kilometre and approximates that this value is $22.7 \mathrm{~g}$. For this 
calculation, they consider average numbers of passengers per train and energy consumption (direct emissions from diesel trains and indirect emissions from diesel and electricity production) $[60,61]$. Regional environment agency provides detailed calculations for public transport buses and private vehicles (electric and conventional) $[62,63]$ while values for bike and walking $\mathrm{CO}_{2}$ emissions are calculated as follows:

$$
\mathrm{CO}_{2} \text { emissions } \text { bike/walk }=\mathrm{CO}_{2} \text { emissions } \text { activity }-\mathrm{CO}_{2} \text { emissions } \text { rest }
$$

where $\mathrm{CO}_{2}$ emissions activity is amount of $\mathrm{CO}_{2}$ emissions person produces by going one kilometre on foot or by bicycle, while $\mathrm{CO}_{2}$ emissions rest corresponds to the $\mathrm{CO}_{2}$ emissions person produces by standing still (resting) for the same amount of time. $\mathrm{CO}_{2}$ emissions activity for biking and walking are calculated as an equivalent of $\mathrm{CO}_{2}$ that person exhales while burning one kcal of energy (Equation (2)). We assume a human consumes/produced $2000 \mathrm{kcal}$ of energy daily and found that roughly equivalent to $0.7 \mathrm{~kg}$ of carbon dioxide a day [64]. For average urban bike riding, we approximated energy burned by an average individual of $70 \mathrm{~kg}$ to be $281 \mathrm{kcal}$ per hour [65] and for walking $544 \mathrm{kcal}$ per hour [66].

$$
\mathrm{CO}_{2} \text { emissions } \text { activity }=\frac{\text { daily }_{\mathrm{CO}_{2}}}{\text { daily }_{\mathrm{kcal}}} \times \mathrm{kcal}_{\text {bike/walk }}
$$

Table 3 summarises obtained values for $\mathrm{CO}_{2}$ emissions for each transport mode.

Table 3. Referent values for $\mathrm{CO}_{2}$ emissions (well-to-wheel) (based on $[59,61]$ ).

\begin{tabular}{cccccccc}
\hline & Train & Bus & Car & e-Car & Bike & Walk & Unit \\
\hline $\mathrm{CO}_{2}$ & 22.7 & 85 & 132 & 38 & $3 \times 10^{-4}$ & $1 \times 10^{-5}$ & $\mathrm{~g} / \mathrm{km}$ \\
\hline
\end{tabular}

\subsubsection{Particulate Matter $\left(\mathrm{PM}_{2.5}\right)$ Emissions}

Particulate matter is microscopic solid or liquid matter suspended in the Earth's atmosphere. Those particulate matters with less than 2.5 micrometres in diameter $\left(\mathrm{PM}_{2.5}\right)$ are considered to be fine $\mathrm{PM}$ that poses the greatest health risks. For every increase of $10 \mu \mathrm{g} / \mathrm{m}^{3}$ of $\mathrm{PM}_{2.5}$ in the air, the lung cancer rate rises $36 \%$ [67]. For this reason, it is considered that there are no safe $\mathrm{PM}_{2.5}$ levels. According to the European Environment Agency findings, just road transport contributes to around 25\% of overall $\mathrm{PM}_{2.5}$ emissions in Europe [68]. As $\mathrm{PM}_{2.5}$ emissions vary dependable upon the type of energy source and type of the vehicle, Table 4 provides summarises of estimated values weighted by the ratio of different vehicle types present in Flemish Brabant province [69].

Table 4. Referent values for $\mathrm{PM}_{2.5}$ emissions (based on [70-72]).

\begin{tabular}{cccccccc}
\hline & Train & Bus & Car & e-Car & Bike & Walk & Unit \\
\hline $\mathrm{PM}_{2.5}$ emission & 0 & $1 \times 10^{-5}$ & $7 \times 10^{-6}$ & 0 & 0 & 0 & $\mathrm{~kg} / \mathrm{km}$ \\
\hline
\end{tabular}

\subsubsection{Calories Burned}

Active transport term refers to human powered transport, such as walking and cycling. It plays important and unique role in an efficient and equitable transport system as it provides basic mobility, affordable transport, and access to other transport modes, minimal emissions, physical fitness, and enjoyment. The benefits of active transport mode use can be summarised as [73]:

- increased capacity, and reduced congestion, in the overall transport network;

- reduced environmental impacts;

- improved public health and reduced healthcare costs;

- improved community wellbeing and social cohesion. 
In order to valorise the benefits of active transport modes as more sustainable mobility options, Table 5 summarises the energy usage of human body while preforming actions like walking or cycling over distance of $1 \mathrm{~km}$ [66]. For the results to be comparable with other indicators considered in this manuscript we took the same characteristics for a referent human (e.g., body weight of $70 \mathrm{~kg}$ and flat surface).

Table 5. Referent values for level of physical activity [66].

\begin{tabular}{cccccccc}
\hline & Train & Bus & Car & e-Car & Bike & Walk & Unit \\
\hline energy & 3 & 3 & 4.5 & 4.5 & 20 & 57 & $\mathrm{kcal} / \mathrm{km}$ \\
\hline
\end{tabular}

\subsubsection{Cost per Trip}

To valorise economic sustainability of different transport modes, we evaluated average cost for one $\mathrm{km}$ of trip travelled by different transport modes in the local context [69] as follows:

$$
\begin{gathered}
B u s_{\text {cost }}=\frac{\text { Price of one ticket }}{\text { Average trip length }} \\
\operatorname{Train}_{\text {cost }}=\frac{\sum_{i}^{n} \frac{\text { Price ot ticket }}{\text { Distance between stations }}}{n}
\end{gathered}
$$

where $n$ is a number of main train stations in cities with population higher than 50,000 inhabitants [74]. Referent values for car are based upon official contribution for companies for work-related car trips [75] while value for bike is based upon Victoria Transport Policy Institute's findings [76] (Table 6).

Table 6. Referent values for cost per km travelled by different transport modes.

\begin{tabular}{cccccccc}
\hline & Train & Bus & Car & e-Car & Bike & Walk & Unit \\
\hline cost & 0.25 & 0.7 & 0.3461 & 0.287 & 0.039 & 0 & $€ / \mathrm{km}$ \\
\hline
\end{tabular}

\section{Enhancing the Urban Sustainability Planning Process with Big Data}

\subsection{Behavioural Change Evaluation}

When considering all users, for $7.4 \%$ of routes they tried out new, more sustainable, route alternatives. The acceptability of this incentive varied among different homogeneous subgroups of users, reaching up to $18 \%$ for Carfree Choosers [33]. Compared with results from literature where traditional communication means were used to familiarize transport system users with available alternatives [77] these results are on average twice higher. This highlights the potential of Policy 2.0 concept applicability. In more detail, the most prominent difference was for the $\mathrm{CO}_{2}$ emissions were, on average, for every newly tried trip suggestion $\mathrm{CO}_{2}$ emission were reduced for $465 \mathrm{~g}$ (Figure 4). In addition, on average, users were more active which resulted in burning 7.4 kcal more per trip than it was the case for their usual mobility behaviour. However, general statistics often hinder insights into distribution of behavioural change across different population segments. Figures 5-8 show in more detail results for each of sustainable mobility indicators across different homogeneous population subgroups.

Regarding the $\mathrm{CO}_{2}$ emissions, the highest reduction of the $\mathrm{CO}_{2}$ emissions per trip was noticeable for the Devoted Drivers (a bit more than $2538 \mathrm{~g}$ ) while the Practical travellers produced $45 \mathrm{~g}$ of $\mathrm{CO}_{2}$ more per trip than usually (Figure 5). Potential reason for this is seen in fact that, when choosing a route, Practical travellers are not predominantly concerned by environmental issues, but by personal feeling of convenience. In this sense, when considering all the available mobility options, they personally prefer faster and cheaper transport modes (Table 2). Thus, geographical distribution of their preferences 
for car routes can provide decision makers with worthy indication about public transport, bike or pedestrian network performance and connectivity.

Similar effect, as for the $\mathrm{CO}_{2}$ emissions, was noticeable for the $\mathrm{PM}_{2.5}$ emissions across different attitudinal profiles (Figure 6).

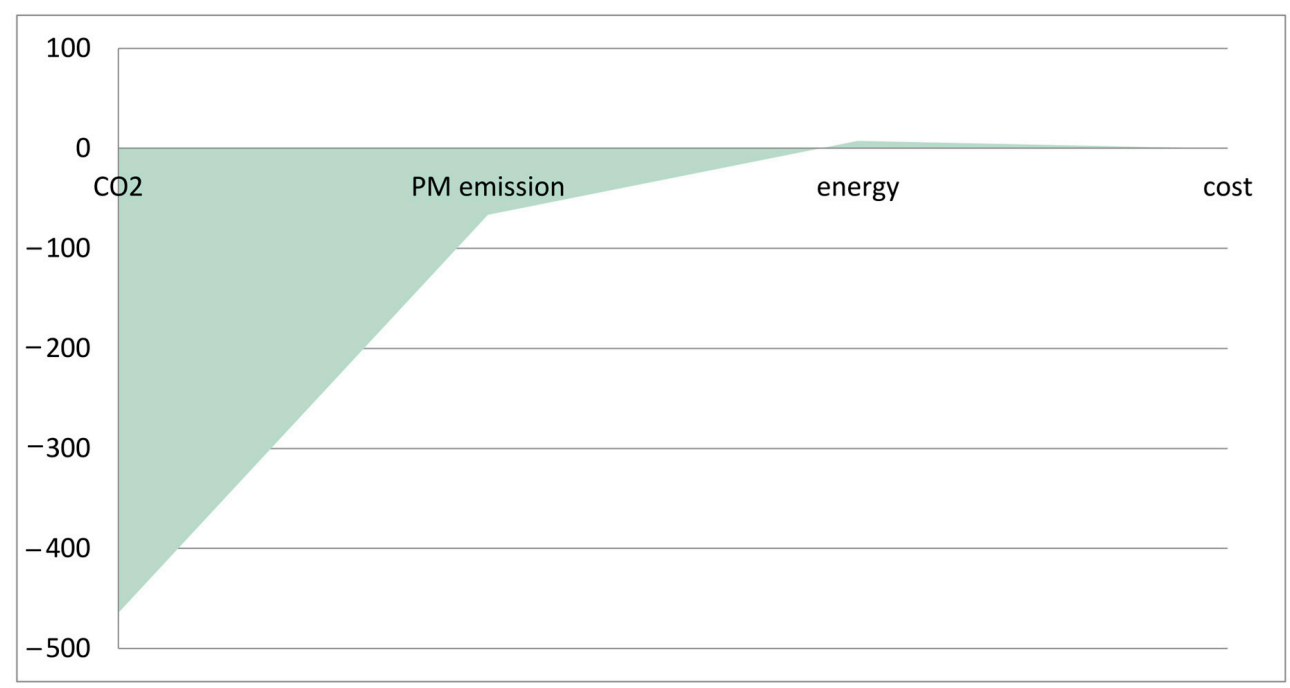

Figure 4. Behavioural change effect per trip.

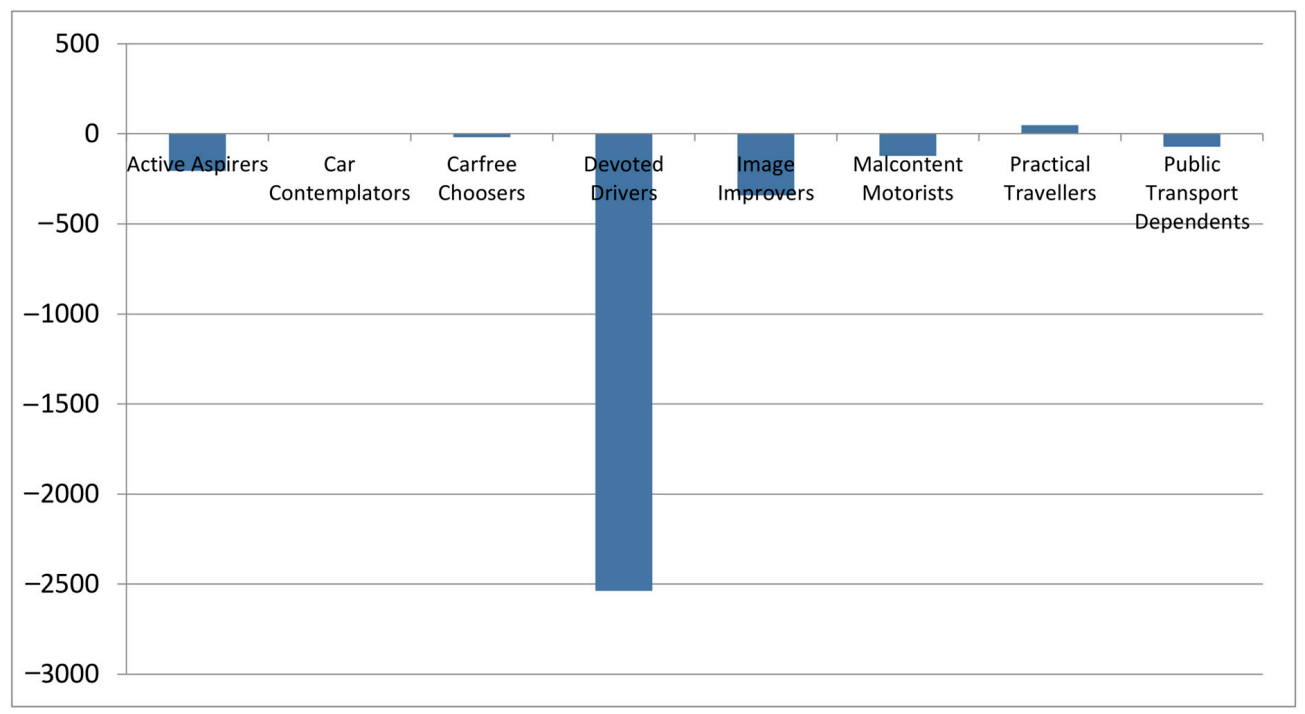

Figure 5. $\mathrm{CO}_{2}$ savings per trip.

Regarding the physical activity, behavioural change effect was most prominent for the Public Transport Dependents who averagely burned $52 \mathrm{kcal}$ more per trip than before (Figure 7). Increase in the level of physical activity was also noticeable for the Malcontent Motorists, Devoted Drivers and Active Aspirers. On the other hand, the Practical Travellers were most likely to change their behaviour in a way that would cause the least physical activity by them. Considering the financial savings, the Devoted Drivers profited the most from the behavioural change by saving, on average, 1.5 Euros per trip. The most pronounced change was also noticeable for other car oriented profiles, such as Image Improvers, where even small difference in mobility behaviour, as choosing shorter car routes or trying out bike and walking for shorter trips, reflected in observed financial savings. Indeed, a small financial loss, of extra 0.01 Euro per trip, was noticeable for Practical Travellers and Carfree Choosers 
(Figure 8). This increase in mobility budget was mainly due to replacing some active transport mode routes by public transport, while the use of private cars maintained low for these profiles.

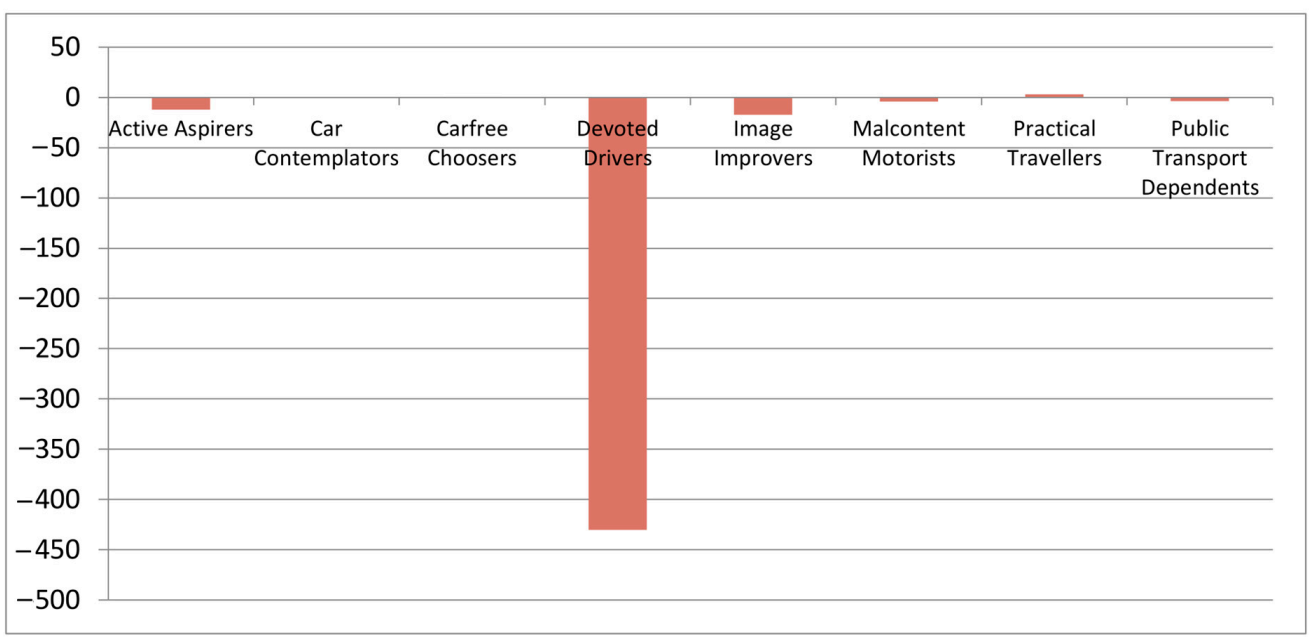

Figure 6. $\mathrm{PM}_{2.5}$ emissions saving per trip.

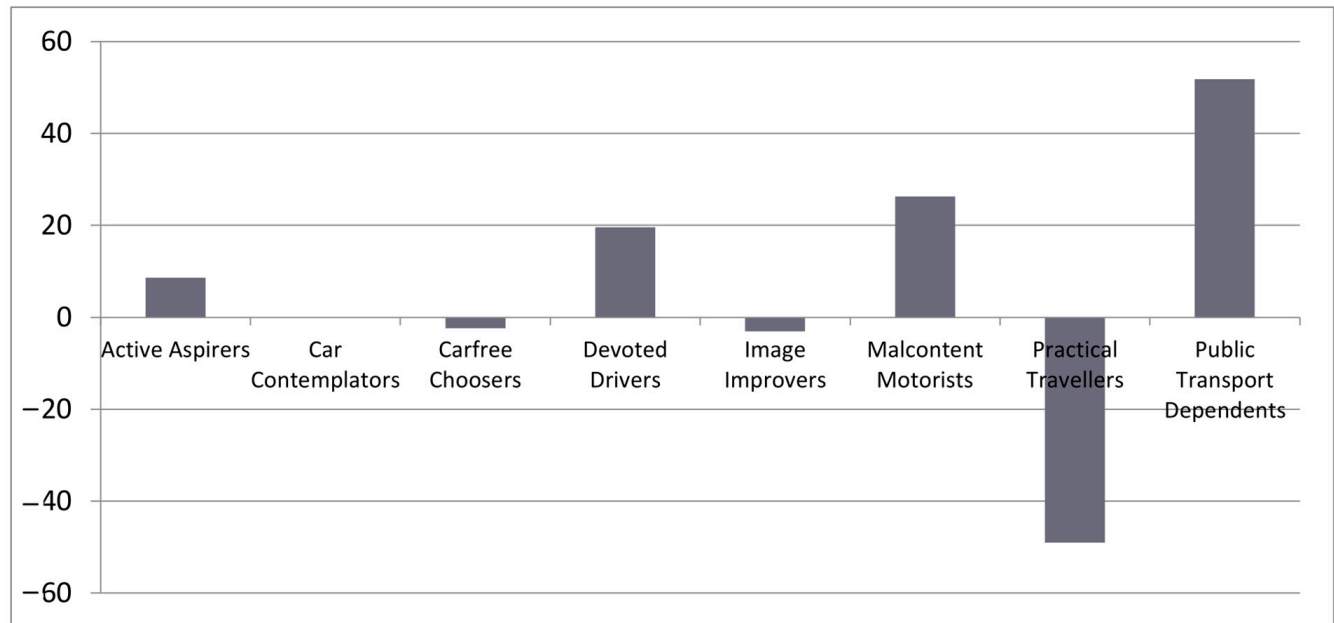

Figure 7. Personal activity level per trip.

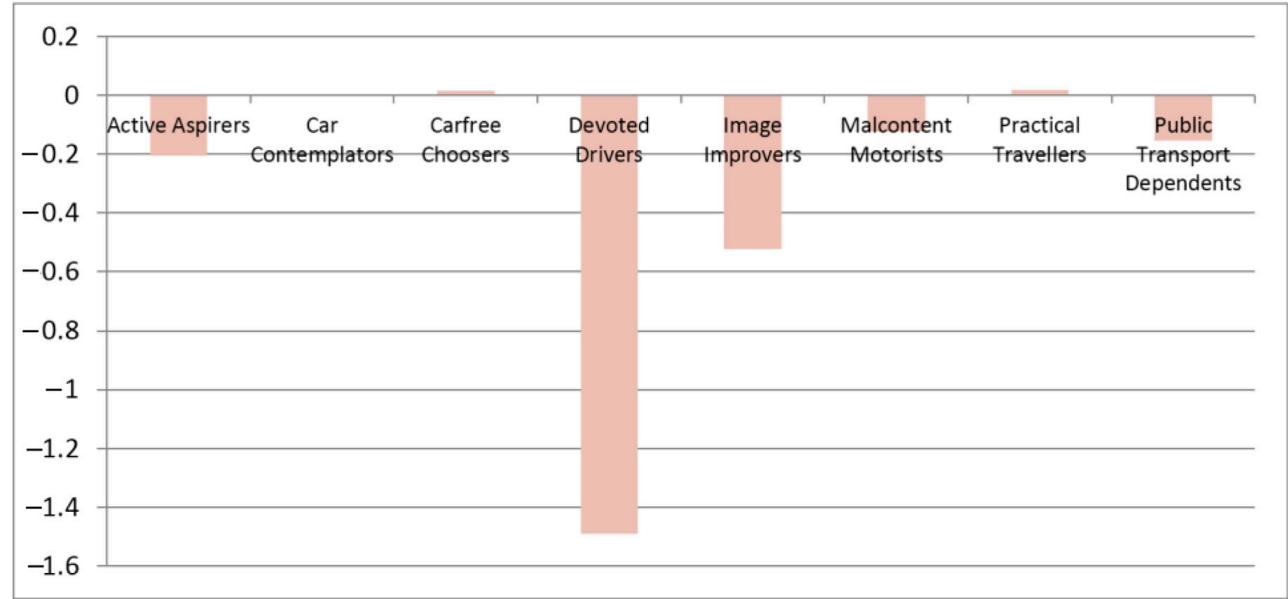

Figure 8. Financial savings per trip. 


\subsection{Urban Sustainability Planning Support}

Integration of direct and derived insights into Policy 2.0 platform has two sided visibility. On one end, users, based on their user profile, can follow up on their personal mobility related statistics, such as mobility budget, but also compare themselves with aggregated values at the population, or homogeneous subgroup, level. On the other end sustainable mobility planners have insight into campaign's participants overall mobility behaviour, which, based on the spatial and temporal resolution, they can aggregate at different levels (such as morning peak hour for certain community, or homogeneous subgroup of users) (Figure 9).

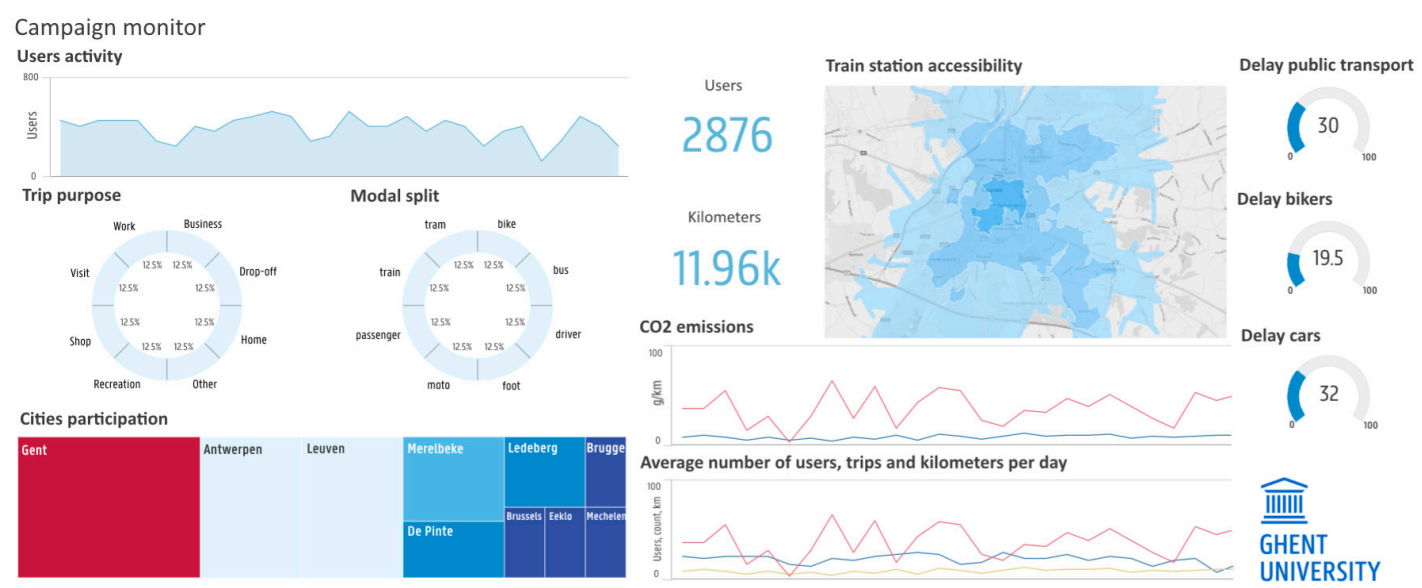

Figure 9. Policy 2.0 dashboard.

Observed traffic flows can provide feedback on accessibility of different parts of the city as city's squares or train station, clearly indicating spatial and temporal creation of bottlenecks. In such cases, mobility system planners can initiate activation of variable traffic sighs to redistribute traffic flows or influence generation of route suggestions, which users are receiving through the Routecoach, so that certain routes are weighted and displayed with lower of higher priority among the route suggestions (Figure 10). Furthermore, compared public transport travel times across different hours, or days, can signal disturbances or overcrowded locations. In such cases planners can consider short term measures like redistributing additional public transport vehicles or identifying locations where traffic police should intervene to facilitate the circulation of the public transport. In repeating occurrences, they can consider redesigning lines or other long term measures. High mobility budget, among usually, not car oriented profiles in certain area, can indicate that bus provision in the area is inadequate. Furthermore, from observed active transport mode routes desired lines can be extracted. This way, campaign participants, are directly confronting decision makers with their mobility needs and thus can easily indicate missing links in the available biking or walking infrastructure. This two-way communication can be realised in even more direct ways, as participants can use their smartphones to submit pictures of damaged infrastructure or road crossing where safe passing is hindered by occlusion. Responsible authorities can follow up on such reporting using the same communication channel. 


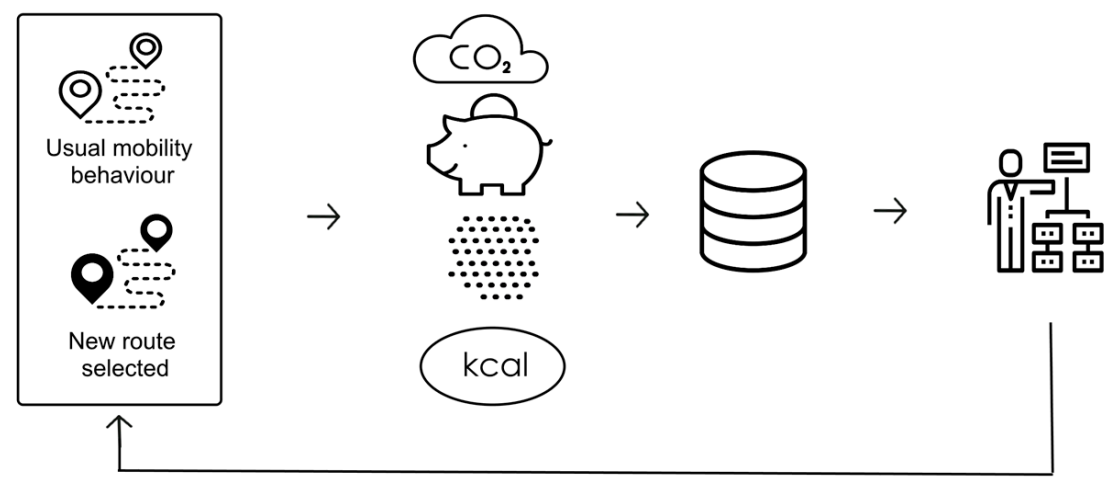

Figure 10. Enhancing the urban sustainability planning process with big data insight.

\section{Discussion}

In this paper, we have defined the Policy 2.0 concept and demonstrate, by means of a real-life example, how big data can be integrated into sustainable mobility planning support systems. Implementation of such planning support system can have multiple implications in favour of improved quality of life and smart and sustainable growth of future urban agglomerations (as demonstrated based on the Policy 2.0 platform example). However, probably the most profound impacts are related to the long term changes in planning process, decision makers-citizen communication and timely content generation, gathered under Policy 2.0 concept umbrella. One of such examples is sustainable mobility planning. Traditionally, data for mobility planning are gathered based on household surveys or interviews. In these surveys, and interviews, participants are asked to indicate their usual mobility behaviour during an average week (including data on trip purposes, frequencies, transportation modes used, etc.). However, previous studies [78] have identified that this way reported mobility behaviour deviates systematically from the actual one. Some examples of such deviations are overestimated travel times for public transport or omitted mentioning of short trips. Furthermore, implementation of such data collection procedure is time and resource demanding and followed by lasting data processing. Usually, the final result is the mobility report which contains necessary inputs for transport planning models such as modal split, average trip lengths, trip frequencies, etc. In the transport planning models, results of reported mobility behaviour are compared with existing mobility infrastructure in the area. Based on these findings, future mobility plans are designed. Average planning cycle for transport system, which consists of issue and problem identification, agenda setting including consideration of alternative development options, analysis, negotiation and decision making, implementation and finally evaluation [79] lasts from 5-20 years, whereas big part of this period goes to data collection-processing chain. By the point when collected data are applicable to support planning and decision making process, it is often questionable how referent and representative they are. Thus, the implementation of the Policy 2.0 concept into transport system planning process has potential to shorten the duration of data collection-processing chain and respectively the whole planning cycle. As data collection-processing chain is shortened, the relevance and timeliness of the data is also improved and the true value of big data potential is realised. Furthermore, based on the real time user generated content, decision makers and planner are imminently confronted with the feedback on the implemented measures. An example of this is construction of a new bike line, or bus stop, and observed usage (or lack of it). Such timely feedbacks have valuable impact of the decision making and planning process as they speed up the learning cycle and enable agile decision making as well as revision and adaption of tactical and strategic plans.

By means of a real life example, we have demonstrated the smartphone app based data collection process, but today also applicability of other mobile phone sourced data is being explored. One of such examples is the use of cellular network's signalisation and call details record data [2,80-82]. Although such data exhibit high potential for future integration into transport system planning 
process, at this phase, their applicability for replacing traditional data collection is still not at mature phase. Probably the most prominent reason for this, from data analytics point of view, is its low spatial and temporal resolution. However, their wider applicability is also hindered by a number of privacy, regulatory, technological and business related issues [83]. In more detail, the Policy 2.0 concept is not sensing device limiting and integration of different sensing technologies under its umbrella is possible and desirable. Indeed, availability of advanced information and communication solutions has beneficial impact on the Policy 2.0 concept adoption, but it is not solely precondition and investments in equipment cannot be seen as proportional to maturity of the Policy 2.0 concept adoption as, the most profound change comes from the shift in a way the role of citizens is perceived. Thus, the adoption of the Policy 2.0 concept is, in itself, a sustainable process that should be in harmony with community's possibilities and needs. In line with this, practical examples of big data integration are still strongly services oriented $[12,13,17]$ and characterized by bottom-up initiatives. However, long term top-down dedication of decision makers towards the big data integration is needed in order to ensure complementarity of different bottom-up initiative and facilitate their future integration. Indeed, due to the fact that availability of the big data is still relatively new, its impact on all levels of decision making and planning process is not uniform. At this point, integration of big data is more likely to be able to support operational planning activities as availability of longitudinal insights (e.g., yearly time series) is still limited. In this sense, its impact on long term planning is yet not strongly demonstrated and future research and developments in this field are expected. Additional limitation, regarding the integration of user generated content is its validation. As user generated content is often subjective and self-edited, additional care should be taken while processing such input. One potential way to overcome validation of user generated content is, for example, to map reported issues (e.g., damaged infrastructure) and allow other campaign participants, while passing in the vicinity of the issue's location, to simply validate its severity. This way reported issues, of same category, can immediately be prioritized and dealt with in line with the obtained feedback. Furthermore, it is to expect that the scope and depth of user engagement will vary, typically in accordance with a city's social and human capital. Positive examples and campaigns designed to attract early adopters can lead to the successful roll out of the platform and encourage more citizens to participate, as well as observable benefits from improved city's assets management and services.

\section{Conclusions}

This paper describes the Policy 2.0 concept, and demonstrates the applicability of the Policy 2.0 platform for smart city's planning support system. Benefits of big data integration into decision making and planning process are manifold. The most obvious ones are related to the improved timeliness of the data, reduced duration of planning cycle and more informed and agile decision making, on both citizens and city planners sides. However, integration of big data into planning process should be graduate and with full awareness of existing limitations at the time.

Acknowledgments: This research is funded by INTERREG North-West Europe project New Integrated Smart Transport Options (NISTO), the Flemish government agency for Innovation by Science and Technology and the Flemish Institute for Mobility.

Author Contributions: Ivana Semanjski contributed by conception and designing of data collection process on attitudinal profiles. She also defined Policy 2.0 concept, analysed and interpreted the data and wrote the paper. Rik Bellens designed and developed the Routecoach application and data integration process. Sidharta Gautama contributed by conception and designing of Policy 2.0 platform. He and Frank Witlox also participated in data interpretation and manuscript evaluation process.

Conflicts of Interest: The authors declare no conflict of interest. The founding sponsors had no role in the design of the study; in the collection, analyses, or interpretation of data; in the writing of the manuscript, and in the decision to publish the results. 


\section{References}

1. Gantz, J.; Reinsel, D. Extracting Value from Chaos; IDC iView: Framingham, MA, USA, 2011.

2. Witlox, F. Beyond the Data Smog? Transp. Rev. 2015, 35, 245-249. [CrossRef]

3. Laney, D. 3-D Data Management: Controlling Data Volume, Velocity and Variety. Available online: https://blogs.gartner.com/doug-laney/files/2012/01/ad949-3D-Data-Management-Controlling-DataVolume-Velocity-and-Variety.pdf (accessed on 31 October 2016).

4. Chen, H.; Roger, C.; Storey, V. Business intelligence and analytics: From big data to big impact. MIS Q. 2012, $36,1165-1188$.

5. Chen, M.; Mao, S.; Liu, Y. Big data: A survey. Mob. Netw. Appl. 2014, 19, 171-209. [CrossRef]

6. Linden, G.; Smith, B.; York, J. Amazon.com Recommendations Item-to-Item Collaborative Filtering. IEEE Internet Comput. 2003, 7, 76-80. [CrossRef]

7. Hasan, L.; Morris, A.; Probets, S. Using Google Analytics to Evaluate the Usability of E-Commerce Sites. In Human Centered Design; Springer: Berlin, Germany, 2009; pp. 697-706.

8. Provost, F.; Fawcett, T. Data Science and its Relationship to Big Data and Data-Driven Decision Making. Data Sci. Big Data 2013, 1, 51-59. [CrossRef]

9. McAfee, A.; Brynjolfsson, E. Big Data: The Management Revolution. Harv. Bus. Rev. 2012, 2012, 59-69.

10. Google. Google Scholar. Available online: http://scholar.google.com (accessed on 24 July 2016).

11. Allwinkle, S.; Cruickshank, P. Creating Smart-er Cities: An Overview. J. Urban Technol. 2011, 18, 1-16. [CrossRef]

12. Hollands, R.G. Will the real smart city please stand up? City 2008, 12, 303-320. [CrossRef]

13. Komninos, N.; Pallot, M.; Schaffers, H. Open Innovation towards Smarter Cities. In Open Innovation; Publications Office of the European Union: Luxemburg, 2013; pp. 34-41.

14. Lombardi, P.; Giordano, S.; Farouh, H.; Yousef, W. Modelling the smart city performance. Innov. Eur. J. Soc. Sci. Res. 2012, 25, 137-149. [CrossRef]

15. Nam, T.; Pardo, T.A. Smart city as urban innovation: Focusing on management, policy, and context. In Proceedings of the 5th International Conference on Theory and Practice of Electronic Governance, Tallinn, Estonia, 26-28 September 2011.

16. Papa, R.; Gargiulo, C.; Galderisi, A. Towards an Urban Planners' Perspective on Smart City. TeMA J. Land Use Mobil. Environ. 2013, 6, 5-17.

17. Angelidou, M. Smart city policies: A spatial approach. Cities 2014, 41, S3-S11. [CrossRef]

18. Debnath, A.K.; Chin, H.C.; Haque, M.M.; Yuen, B. A methodological framework for benchmarking smart transport cities. Cities 2014, 37, 47-56. [CrossRef]

19. Neirotti, P.; de Marco, A.; Cagliano, A.C.; Mangano, G.; Scorrano, F. Current trends in Smart City initiatives: Some stylised facts. Cities 2014, 38, 25-36. [CrossRef]

20. Yamagata, Y.; Seya, H. Simulating a future smart city: An integrated land use-energy model. Appl. Energy 2013, 112, 1466-1474. [CrossRef]

21. Dameri, R.P. Searching for Smart City definition: A comprehensive proposal. Int. J. Comput. Technol. 2013, 11, 2544-2551.

22. Gibbs, D.; Krueger, R.; MacLeod, G. Grappling with Smart City Politics in an Era of Market Triumphalism. Urban Stud. 2013, 50, 2151-2157. [CrossRef]

23. Lazaroiu, G.C.; Roscia, M. Definition methodology for the smart cities model. Energy 2012, 47, $326-332$. [CrossRef]

24. Piro, G.; Cianci, I.; Grieco, L.; Boggia, G.; Camarda, P. Information centric services in Smart Cities. J. Syst. Softw. 2014, 88, 169-188. [CrossRef]

25. Filipponi, L.; Vitaletti, A.; Landi, G.; Memeo, V.; Laura, G.; Pucci, P. Smart City: An Event Driven Architecture for Monitoring Public Spaces with Heterogeneous Sensors. In Proceedings of the 4th International Conference on Sensor Technologies and Applications, Venice, Italy, 18-25 July 2010.

26. Wan, J.; Li, D.; Zou, C.; Zhou, K. M2M communications for smart city: An event-based architecture. In Proceedings of the 12th International IEEE Conference on Computer and Information Technology, Chengdu, Sichuan, China, 27-29 October 2012. 
27. Versichele, M.; Neutens, T.; Delafontaine, M.; van de Weghe, N. The use of Bluetooth for analysing spatiotemporal dynamics of human movement at mass events: A case study of the Ghent Festivities. Appl. Geogr. 2012, 32, 208-220. [CrossRef]

28. Balakrishna, C. Enabling Technologies for Smart City Services and Applications. In Proceedings of the 6th International Conference on Next Generation Mobile Applications, Services, and Technologies, Paris, France, 12-14 September 2012.

29. Semanjski, I.; Gautama, S. Smart City Mobility Application—Gradient Boosting Trees for Mobility Prediction and Analysis Based on Crowdsourced Data. Sensors 2015, 15, 15974-15987. [CrossRef]

30. GSMA; Accenture; Cisco. Smart Mobile Cities: Opportunities for Mobile Operators to Deliver Intelligent Cities. Available online: http://www.gsma.com/connectedliving/wp-content/uploads/2012/ 03/intelligentcitiesreport0411lores.pdf (accessed on 31 October 2016).

31. Lee, J.H.; Hancock, M.G.; Hu, M.C. Towards an effective framework for building smart cities: Lessons from Seoul and San Francisco. Technol. Forecast. Soc. Chang. 2014, 89, 80-99. [CrossRef]

32. Vanolo, A. Smartmentality: The Smart City as Disciplinary Strategy. Urban Stud. 2013, 1-16. [CrossRef]

33. Semanjski, I.; Lopez Aguirre, A.J.; de Mol, J.; Gautama, S. Policy 2.0 Platform for Mobile Sensing and Incentivized Targeted Shifts in Mobility Behavior. Sensors 2016, 16, 1035. [CrossRef]

34. DiNucci, D. Fragmented Future. Print 1999, 53, 220-222.

35. Van Peborgh, E. Sustainability 2.0; Odiseo: Buenos Aires, Argentina, 2008.

36. Nidumolu, R.; Prahalad, C.; Rangaswami, M. Why Sustainability Is Now the Key Driver of Innovation. Harv. Bus. Rev. 2009, 9, 13-26.

37. OpenStreetMap Foundation. OpenStreetMap. Available online: https://www.openstreetmap.org (accessed on 31 July 2016).

38. Humanitarian OpenStreetMap Team. Earthquake in Ecuador, Manta-Post-Event Imagery. Available online: http:/ /tasks.hotosm.org/project/2042 (accessed on 1 August 2016).

39. Humanitarian OpenStreetMap Team. Nepal Earthquake Mapping_Langtang Rasuwa (Highly Effected Area). Available online: http://tasks.hotosm.org/project/1016 (accessed on 1 August 2016).

40. Humanitarian OpenStreetMap Team. Adamawa Region Cameroon-Polio Outbreak and Preparedness for other Outbreaks. Available online: http://tasks.hotosm.org/project/1087 (accessed on 1 August 2016).

41. Joshi, P. Brussels Lockdown Hashtag Sparks Hilarious Cat-Storm on Social Media. Available online: http:/ / www.ibtimes.co.uk/brussels-lockdown-hashtag-sparks-hilarious-cat-storm-social-media-1529980 (accessed on 16 July 2016).

42. Tutt, P.; Pramuk, J. Brussels Lockdown: Highest Alert Level Maintained. Available online: http://www.cnbc. com/2015/11/22/brussels-lockdown-arrests-made-shots-fired-in-salah-abdeslam-hunt.html (accessed on 16 July 2016).

43. Baert, D.; van Poucke, S. Politie Bedankt Hulpvaardige Katten op Twitter. Available online: http://deredactie. be/cm/vrtnieuws/cultuur\%2Ben\%2Bmedia/1.2504148 (accessed on 16 July 2016).

44. New Integrated Smart Transport Options. Available online: http://www.nisto-project.eu/en/home.html (accessed on 2 August 2016).

45. Ghent University. Routecoach; Ghent University: Ghent, Belgium, 2015. Available online: http://www. routecoach.be/ (accessed on 2 August 2016).

46. City of Leuven. Leuven Population Statistics. 2015. Available online: http://www.leuven.be/bestuur/ leuven-in-cijfers/bevolking/aantal-inwoners/ (accessed on 29 August 2016).

47. Segment. Segmented Marketing for Energy Efficient Transport. 2013. Available online: http://www. segmentproject.eu/ (accessed on 1 December 2015).

48. Ajzen, I. The theory of planned behaviour. Organ. Behav. Hum. Decis. Process. 1991, 50, 179-211. [CrossRef]

49. Anable, J.; Wright, S. Segment. 2013. Available online: http://www.segmentproject.eu/hounslow/segment. nsf/Files/SFF-266/ \protect \T1 \textdollarfile/Deliverable\%207.8.4\%20GOLDEN\%20QUESTIONS\% 20AND\%20SOCIAL\%20MARKETING\%20GUIDANCE\%20REPORT.pdf (accessed on 18 November 2015).

50. Ladbury, P. Segment Toolkit. 1 July 2013. Available online: http://www.segmentproject.eu/hounslow/ segment.nsf/Files/SFF-318/ protect \T1\textdollarfile/Deliverable\%207-8.3\%20Social\%20Marketing\% 20Toolkit.pdf (accessed on 20 May 2015).

51. Semanjski, I.; Gautama, S. Crowdsourcing mobility insights-Reflection of attitude based segments on high resolution mobility behaviour data. Transp. Res. Part C Emerg. Technol. 2016, 71, 434-446. [CrossRef] 
52. Move. Google Play, Routecoach; Ghent University: Ghent, Belgium, 2015. Available online: https://play. google.com/store/apps/details?id=com.move.routecoach\&hl=nl_BE (accessed on 2 February 2016).

53. Cioca, L.I.; Ivascu, L.; Rada, E.C.; Torretta, V.; Ionescu, G. Sustainable development and technological impact on $\mathrm{CO}_{2}$ reducing conditions in Romania. Sustainability 2015, 7, 1637-1650. [CrossRef]

54. United Nations. Kyoto Protocol to the United Nations Framework Convention on Climate Change; United Nations: Bonn, Germany, 1998.

55. Gillis, D.; Semanjski, I.; Lauwers, D. How to Monitor Sustainable Mobility in Cities? Literature Review in the Frame of Creating a Set of Sustainable Mobility Indicators. Sustainability 2016, 8, 29. [CrossRef]

56. Mira Milieurapport Vlaanderen. Achtergrond Rapport Transport (Environmental Report Flanders-Background Report on Transport); Milieurapport Vlaanderen MIRA: Mechelen, Belgium, 2010.

57. Worldbank. Worldbank. 2013. Available online: http://data.worldbank.org/indicator/EN.CO2.TRAN.MT (accessed on 20 May 2015).

58. United States Environmental Protection Agency. Guide to Sustainability Transportation Performance Measures; United States Environmental Protection Agency: Washington, DC, USA, 2011.

59. European Commission \& AmbientItalia. European Common Indicators; European Commission: Brussels, Belgium, 2003.

60. NMBS Group. $\mathrm{CO}_{2}$-Emissies Treinverkeer. Available online: http://www.belgianrail.be/nl/corporate/ duurzaamheid/planet/ /media/C6FAF258787F41FAB7A6CADDB409422D.ashx (accessed on 31 October 2016).

61. NMBS-Groep. Plan Duurzaam Ondernemen; NMBS: Brussel, Belgium, 2015.

62. Flanders Environment Agency. MIRA Indicator Report; Flanders Environment Agency: Aalst, Belgium, 2012.

63. De Lijn. $\mathrm{CO}_{2}$ Uitstoot Verkee. Available online: https://www.delijn.be/nl/overdelijn/organisatie/ zorgzaam-ondernemen/milieu/co2-uitstoot-voertuigen.html (accessed on 20 August 2016).

64. Goldemberg, J.; Lucon, O. Energy, Environment and Development; Cromwell Press Group: Trowbridge, UK, 2009.

65. Bicycling. Cycling Calories Burned Calculator. Available online: http://www.bicycling.com/training/ weight-loss/cycling-calories-burned-calculator (accessed on 1 September 2016).

66. ShapeSense. Walking Calorie Burn Calculator. Available online: http://www.shapesense.com/fitnessexercise/calculators/walking-calorie-burn-calculator.shtml (accessed on 1 September 2016).

67. Raaschou-Nielsen, O.; Andersen, Z.J.; Beelen, R.; Samoli, E.; Stafoggia, M.; Weinmayr, G.; Hoffmann, B.; Fischer, P.; Nieuwenhuijsen, M.J.; Brunekreef, B.; et al. Air pollution and lung cancer incidence in 17 European cohorts: Prospective analyses from the European Study of Cohorts for Air Pollution Effects (ESCAPE). Lancet Oncol. 2013, 14, 813-822. [CrossRef]

68. European Environment Agency. National Emissions Reported to the Convention on Long-Range Transboundary Air Pollution (LRTAP Convention); European Environment Agency: Copenhagen, Denmark, 2016.

69. Mobiel Vlaanderen. Onderzoek Verplaatsingsgedrag Vlaams-Brabant; Mobiel Vlaanderen: Brussel, Belgium, 2014.

70. Vankerkom, J.; de Vlieger, I.; Schrooten, L.; Vliegen, J.; Styns, K. Beleidsondersteunend Onderzoek: Aanpassingen aan het Emissiemodel Voor Wegtransport MIMOSA; VITO: Mol, Belgium, 2009.

71. Gillies, J.A.; Gertler, A.W.; Sagebiel, J.C.; Dippel, W.A. On-road particulate matter $\left(\mathrm{PM}_{2.5}\right.$ and $\left.\mathrm{PM}_{10}\right)$ emissions in the Sepulveda Tunnel, Los Angeles, California. Environ. Sci. Technol. 2001, 35, 1054-1063. [CrossRef]

72. Cai, H.; Burnham, A.; Wang, M. Updated Emission Factors of Air Pollutants from Vehicle Operations in GREETTM Using MOVES; Argonne National Laboratory: Lemont, IL, USA, 2013.

73. Department of Infrastructure and Transport. Walking, Riding and Access to Public Transport; Department of Infrastructure and Transport: Canberra, Australia, 2013.

74. Belgian Federal Government. Statistics Belgium; Belgian Federal Government: Brussels, Belgium, 2013.

75. Federal Planning Bureau. The Fiscal Treatment of Company Cars in Belgium; Federal Planning Bureau: Brussels, Belgium, 2016.

76. Victoria Transport Policy Institute. Transportation Cost and Benefit Analysis II-Vehicle Costs; Victoria Transport Policy Institute: Victoria, BC, Canada, 2015.

77. Ishfaq, S.; Anable, J. SEGMENT Work Package 6-Final Report; London Borough of Hounslow: London, UK, 2013.

78. Stopher, P.; Greaves, S.P. Household travel surveys: Where are we going? Transp. Res. Part A Policy Pract. 2007, 41, 367-381. [CrossRef] 
79. Khan, Z.; Ludlow, D.; Loibl, W.; Soomro, K. ICT enabled participatory urban planning and policy development: The UrbanAPI project. Transform. Gov. People Process Policy 2014, 8, 205-229. [CrossRef]

80. Järv, O.; Ahas, R.; Saluveer, E.; Derudder, B.; Witlox, F. Mobile phones in a traffic flow: A geographical perspective to evening rush hour traffic analysis using call detail records. PLoS ONE 2012, 7, e49171. [CrossRef]

81. Järv, O.; Ahas, R.; Witlox, F. Understanding monthly variability in human activity spaces: A twelve-month study using mobile phone call detail records. Transp. Res. C Emerg. Technol. 2014, 38, 122-135. [CrossRef]

82. Semanjski, I.; Gautama, S. Sensing Human Activity for Smart Cities' Mobility Management. In Smart Cities Technologies; InTech: Rijeka, Croatia, 2016, in press.

83. Ahas, R.; Armoogum, J.; Esko, S.; Ilves, M.; Karus, E.; Madre, J.-L.; Nurmi, O.; Potier, F.; Schmücker, D.; Sonntag, U.; et al. Feasibility Study on the Use of Mobile Positioning Data for Tourism Statistics; Eurostat: Luxemburg, 2014.

(C) 2016 by the authors; licensee MDPI, Basel, Switzerland. This article is an open access article distributed under the terms and conditions of the Creative Commons Attribution (CC-BY) license (http://creativecommons.org/licenses/by/4.0/). 